\title{
De novo gonad transcriptome analysis of the common littoral shrimp Palaemon serratus: novel insights into sex-related genes
}

\author{
Inés González-Castellano ${ }^{1^{*}}$ (D), Chiara Manfrin ${ }^{2}$, Alberto Pallavicini ${ }^{2}$ and Andrés Martínez-Lage ${ }^{1^{*}}$
}

\begin{abstract}
Background: The common littoral shrimp Palaemon serratus is an economically important decapod resource in some European communities. Aquaculture practices prevent the genetic deterioration of wild stocks caused by overfishing and at the same time enhance the production. The biotechnological manipulation of sex-related genes has the proved potential to improve the aquaculture production but the scarcity of genomic data about $P$. serratus hinders these applications. RNA-Seq analysis has been performed on ovary and testis samples to generate a reference gonadal transcriptome. Differential expression analyses were conducted between three ovary and three testis samples sequenced by Illumina HiSeq 4000 PE100 to reveal sex-related genes with sex-biased or sex-specific expression patterns.
\end{abstract}

Results: A total of 224.5 and 281.1 million paired-end reads were produced from ovary and testis samples, respectively. De novo assembly of ovary and testis trimmed reads yielded a transcriptome with 39,186 transcripts. The $29.57 \%$ of the transcriptome retrieved at least one annotation and 11,087 differentially expressed genes (DEGs) were detected between ovary and testis replicates. Six thousand two hundred seven genes were up-regulated in ovaries meanwhile 4880 genes were up-regulated in testes. Candidate genes to be involved in sexual development and gonadal development processes were retrieved from the transcriptome. These sex-related genes were discussed taking into account whether they were up-regulated in ovary, up-regulated in testis or not differentially expressed between gonads and in the framework of previous findings in other crustacean species.

Conclusions: This is the first transcriptome analysis of $P$. serratus gonads using RNA-Seq technology. Interesting findings about sex-related genes from an evolutionary perspective (such as Dmrt1) and for putative future aquaculture applications (lag or vitellogenesis genes) are reported here. We provide a valuable dataset that will facilitate further research into the reproductive biology of this shrimp.

Keywords: Shrimp, Sex-related, Ovary, Testis, RNA-Seq, Transcriptome, DEG, Aquaculture

\section{Background}

The common littoral shrimp Palaemon serratus (Pennant, 1777) is a crustacean decapod with a geographical distribution ranging the Atlantic Ocean (from Scotland and Denmark to Mauritania, including Azores, Madeira and Canary Islands) and the entire Mediterranean Sea and the

\footnotetext{
* Correspondence: ines.gonzalez.castellano@udc.es; andres@udc.es ${ }^{1}$ Universidade da Coruña, Departamento de Biología and Centro de Investigaciones Científicas Avanzadas (CICA), 15071 A Coruña, Spain Full list of author information is available at the end of the article
}

Black Sea [1]. This species inhabits the intertidal and subtidal soft-sediment of estuaries in the reproductive season, and rocky bottoms covered with seagrass and algae $[2,3]$. Palaemon serratus fishing activity is crucial in some European communities, mainly around the British Isles, France and northern Spain [4]. In Galicia (NW Spain) the volume of catches varies from 47.6 to 90.7 tons traded per year, what equals to worth of 2 million euros per year in this region (data obtained from https://www.pescadegalicia.gal/ on 26 Sep 2018, Xunta de Galicia). The high commercial

(c) The Author(s). 2019 Open Access This article is distributed under the terms of the Creative Commons Attribution 4.0 International License (http://creativecommons.org/licenses/by/4.0/), which permits unrestricted use, distribution, and 
value of this species could possibly lead to overfishing [4]. Implementation of proper management measures that ensure a sustainable exploitation will prevent depletion or genetic deterioration of wild fisheries [5, 6]. Aquaculture practices might improve $P$. serratus production at once reduce the fishing pressure over the wild populations.

In the field of aquaculture, reproductive traits are considered economically significant. Hence, understanding sexual and reproductive development is necessary to obtain successful and sustainable cultures, to increase seed quality or to breed genetically improved lines $[7,8]$. For instance, as sex dimorphism in growth is common in crustaceans, monosex aquaculture of commercially relevant species is especially interesting. In monosex populations the yield is increased because energy from reproduction is invested in growth, resulting in larger-size individuals than in sex-mixed cultures $[9,10]$. A better knowledge about the genetics of crustacean sexual development facilitates the application of biotechnological strategies, such as sexchange induction, benefiting productivity [7].

Sexual development includes sex determination and sex differentiation processes. In Decapoda, sex is determined by the initiation of a genetic cascade triggered by a master sex-determining gene. Downstream genes in this cascade act as sex-regulator genes, leading to the sex differentiation pathway, which in turn results in a sex-specific phenotype development [11]. Due to the lack of genomic information in crustacean decapods, sex-determining genes have not been identified and even sex-related genes have been rarely reported [9]. Several genes are considered preliminary candidates to be implicated in decapod sex determination but since these genes have been identified through homology screening, the list is heavily biased by genes characterized in model species as Drosophila melanogaster, Caenorhabditis elegans and Mammalia (e.g. Sxl, Tra, Tra-2, Dsx, Fem-1 or Sry; see review in [11]). Among these candidates, it is noteworthy to highlight that Dmrt genes (doublesex and male abnormal-3-related transcription factors) have been noted as the only gene family with a conserved function in sex determination across metazoans [11, 12], so they are particularly intriguing. About sex differentiation, the insulin-like androgenic factor (IAG) is a well characterized hormone with a conserved central role in Malacostraca. Iag expression in the androgenic gland (AG) leads sexual differentiation to maleness by governing the onset of testicular and secondary-sex characteristics development in males. Upstream in the sex differentiation pathway, an array of neuropeptides secreted by the eyestalk regulates the Iag expression [11]. It was shown that AGimplanted females become males, and conversely AGablated males turned into females (see review in [13]). As this surgical procedure implies a high mortality rate, it has been recently achieved that Iag-silenced males shifted phenotypically into females in the prawn Macrobrachium rosenbergii [14]. Thus, the biotechnological manipulation of the expression of sex determination or sex differentiation genes has the potential to improve the aquaculture production, such as creating monosex populations among other possibilities. Nevertheless, prior to the implementation of any genetic manipulation technique, it is necessary a depth-understanding about the genetic factors underlying the sexual development in P. serratus.

RNA-Seq greatly enhances the capability for gene discovery in non-model organisms where genomic data is not available. Transcriptome profiling using highthroughput sequencing allows the identification of transcripts involved in biological processes [15]. Comparative transcriptomics and differential expression analyses (DEA) between female and male reproductive tissues enable the detection of transcripts with sex-biased and sex-specific expression. In fact, sex determination and sex differentiation genes have been identified in several commercial decapod species thanks to transcriptomic analyses of certain tissues, including gonads [9, 16-18].

Genetic studies in P. serratus are scarce and mainly focused in its population genetics and cytogenetics. Solely one transcriptomic work is available for this species, providing data to study larval development and metamorphosis [19]. Regarding to sex determination in $P$. serratus, it is only known that heteromorphic sex chromosomes are absent [20]. No sex determination or sex differentiation genes or pathways have been reported for this shrimp. Accordingly, the aim of the present study was to identify candidate genes to be involved in the sexual development of $P$. serratus. For this purpose, an ovary and testis transcriptome was assembled and annotated from Illumina high-throughput sequencing reads, and genes with differential expression between ovarian and testicular tissues were studied. To the best of our knowledge, this is the first work that address the transcriptome profile analysis of both male and female $P$. serratus gonads, providing new data about sex-related genes in this species.

\section{Results \\ Quality control, trimming, de novo assembly and mapping}

Illumina paired-end sequencing generated 525,605,992 raw reads $(244,543,276$ and 281,062,716 raw reads from ovary and testis samples, respectively), corresponding to 26.30 GB of sequence data (12.10 GB and 14.20 GB from ovary and testis, respectively). Raw reads are stored into the NCBI Sequence Read Archive database under accession numbers SRR8631955-SRR8631960. After the trimming and filtering steps a total of $196,658,624$ cleaned reads were recovered from female and 245,684,318 from 
male samples, for a total of 442,342,942 reads survived the processing. De novo Trinity assembly from both ovary and testis reads together produced 328,495 assembled transcripts. BUSCO revealed a $97.6 \%$ of transcriptome completeness, indicating a high quality de novo assembly. As the proportion of duplicates was high (64\%), the EvidentialGene tr2aacds pipeline was used to reduce the transcriptome redundancy. The nonredundant transcriptome consisted in 79,796 transcripts with also a high level of completeness (97\%), and only a resulting $4.6 \%$ of duplicates. De novo assembly statistics are summarised in Table 1. All female and male reads were mapped back together on the non-redundant transcriptome and only transcripts with an expression value of TPM $\geq 1$ were included in the final set of transcripts. After removing ribosomal- and mitochondrial-related transcripts, the final ovary and testis non-redundant transcriptome consisted in 39,186 transcripts.

\section{Functional annotation}

A total of 11,586 assembled transcripts (29.57\%) were annotated at least against one of the used databases (Additional file 1: Table S1). Therefore, the $70.43 \%$ of the ovary and testis transcriptome remained unannotated. Number of transcripts matching each annotation category is listed in Table 2. BLASTx searches against the UniProtKB/Swiss-Prot database identified 17,285 transcripts from 437 species. As UniProtKB/Swiss-Prot is a reviewed database, the BLASTx top hit species were

Table 1 Summary statistics of Palaemon serratus gonads transcriptome sequencing and assembly

\begin{tabular}{|c|c|c|c|c|}
\hline & $\begin{array}{l}\text { Ovary } \\
\text { samples }\end{array}$ & $\begin{array}{l}\text { Testis } \\
\text { samples }\end{array}$ & $\begin{array}{l}\text { Redundant } \\
\text { transcriptome }\end{array}$ & $\begin{array}{l}\text { Non-redundant } \\
\text { transcriptome }\end{array}$ \\
\hline $\begin{array}{l}\text { Number of raw } \\
\text { reads }\end{array}$ & $\begin{array}{l}244,543, \\
276\end{array}$ & $\begin{array}{l}281,062 \\
716\end{array}$ & - & - \\
\hline Raw reads length & 101 & 101 & - & - \\
\hline $\begin{array}{l}\text { Number of reads } \\
\text { after trimming }\end{array}$ & $\begin{array}{l}196,658, \\
624\end{array}$ & $\begin{array}{l}245,684 \\
318\end{array}$ & - & - \\
\hline $\begin{array}{l}\text { Reads length } \\
\text { after trimming }\end{array}$ & $40-86$ & $40-86$ & - & - \\
\hline $\begin{array}{l}\text { Number of } \\
\text { Trinity genes }\end{array}$ & - & - & 165,152 & 69,481 \\
\hline $\begin{array}{l}\text { Number of } \\
\text { Trinity transcripts }\end{array}$ & - & - & 328,495 & 79,796 \\
\hline $\begin{array}{l}\text { Total size of } \\
\text { transcripts (bp) }\end{array}$ & - & - & $268,430,756$ & $77,857,728$ \\
\hline $\begin{array}{l}\text { Mean transcript } \\
\text { size (bp) }\end{array}$ & - & - & 817.15 & 975.71 \\
\hline $\begin{array}{l}\text { N50 transcript } \\
\text { length (bp) }\end{array}$ & - & - & 1744 & 1996 \\
\hline $\begin{array}{l}\text { Assembly } \\
\text { completeness }\end{array}$ & - & - & $97.60 \%$ & $97.0 \%$ \\
\hline $\begin{array}{l}\text { Assembly } \\
\text { duplication }\end{array}$ & - & - & $64.0 \%$ & $4.6 \%$ \\
\hline
\end{tabular}

Table 2 Overview of functional annotation results

\begin{tabular}{ll}
\hline & Number of transcripts \\
\hline UniProtKB/Swiss-Prot BLASTx hits & 17,285 \\
ORF-containing transcripts: & 18,312 \\
5' partial & 3340 \\
internal partial & 2468 \\
complete & 10,843 \\
3' partial & 1661 \\
UniProtKB/Swiss-Prot BLASTp hits & 15,961 \\
PFAM hits & 182,498 \\
Signal peptide domains & 1492 \\
TmHMM domains & 2790 \\
GO assigment: & 6846 \\
Cellular Component & 1809 \\
Molecular Function & 5952 \\
Biological Process & 3155 \\
\hline
\end{tabular}

model species, e.g. Homo sapiens (2547 sequence hits), Mus musculus (1749 hits), Drosophila melanogaster (1619 hits), Rattus norvergicus (581 hits) or Bos taurus (540 hits). TransDecoder found 18,312 putative ORFs (Open Reading Frames) in the assembled transcripts and about $59 \%$ of them were full-length. A total of 15,961 out of these protein-coding candidate transcripts returned a BLASTp hit when they were searched against the known proteins of the UniProtKB/Swiss-Prot database. Searches against the PFAM protein domain database retrieved 182,498 hits on the putative peptides. Of these ORFs, 1492 were predicted to contain a secretion domain and 2790 were predicted to contain at least one transmembrane helix domain. The assembled transcripts were also annotated with Gene Ontology (GO) terms according to the three major GO categories: cellular component, molecular function, and biological process. A total of 13,960 GO terms were assigned and 6846 transcripts $(17.47 \%$ of the transcriptome) were associated with at least one term. Accurately, 1809 transcripts were assigned to a cellular component category, 5952 to a molecular function category, and 3155 to a biological process category.

\section{Differential expression and enrichment analyses}

Clean reads from each sample were mapped back on the non-redundant ovary and testis transcriptome. The percentage of mapped reads oscillated from 65.66 to $73.34 \%$ among samples. At the same time, larvae and muscle reads downloaded from the SRA (SRR4341161-2 and SRR4341163-4, respectively) were cleaned and also mapped separately on the ovary and testis transcriptome in order to identify genes with a gonad-biased expression. The percentage of mapping ranged from $27.83 \%$ 
mapped reads for larvae to $32.68 \%$ mapped reads for muscle. Gene expression of the assembled transcripts in the larvae and muscle samples was calculated and pairwise differential expression analyses (DEAs) were performed between gonad and non-gonad samples (ovaries vs. larvae, ovaries vs muscle, testes vs larvae and testes vs muscle). Genes with a False Discovery Rate (FDR) $p$ value $\leq 0.01$ and a fold-change $>2$ were consider significatively up-regulated in the gonad tissues respecting to the non-gonad tissues. A total of 1961 and 774 genes were identified as up-regulated in ovaries with regard to larvae and to muscle, respectively. As for testes, 1338 and 1118 genes were detected as up-regulated with regard to larvae and to muscle, respectively. By removing duplicated up-regulated genes shared by both female and male gonads, 3646 genes were considered as upregulated genes in both gonads and so they were tagged with a 'G' (gonad up-regulated) in the transcriptome annotation table (Additional file 1: Table S1).

A DEA was carried out between ovary and testis libraries to identify DEGs between sexes and therefore, putative sex-related genes. Transcripts with a FDR $p$ value $\leq 0.01$ and an absolute value of fold-change $>2$ were considered to be significative DEGs. Overall, 11, 087 transcripts were identified as DEGs (Additional file 2: Figure S1). Among these DEGs, the 39.09\% out of them had an annotation from at least one of the used databases, and 6207 genes were up-regulated in ovaries meanwhile 4880 genes were up-regulated in testes (Additional file 1: Tables S2 and Additional file 1: Table S3). A gene was considered ovary- or testis-specifically expressed when its TPM value were less than 1 in the three testis or ovary samples, respectively. The $78.22 \%$ of the genes previously identified as gonad up-regulated genes (G-genes) matched with DEGs between ovaries and testes. Fine scale comparative results from the different DEAs are shown in Table 3.

Comparative GO classification distribution of the annotated genes showed no large differences between DEGs and the entire gonadal transcriptome (Fig. 1a). Statistically, GO enrichment analyses were performed and a $p$-value $\leq 0.01$ was considered as threshold to identify putative functional differences between DEGs and the ovary and testis transcriptome. Based on these GO analyses, 3 GO terms were found to be significantly enriched in DEGs in the cellular component category, 'extracellular region', 'integral component of membrane' and 'membrane'. There were 18 significantly enriched GO terms in DEGs at the molecular function category, being the most enriched terms 'ionotropic glutamate receptor activity', 'chitin binding' and 'G protein-coupled receptor activity'. As for the biological process level, 8 GO terms showed significative enrichment in DEGs, corresponding the most enriched assignations to 'chitin
Table 3 Results of Differential Expression Analysis between ovary and testis simples

\begin{tabular}{ll}
\hline & Number of transcripts \\
\hline $\begin{array}{l}\text { Ovary and testis } \\
\text { transcriptome }\end{array}$ & 39,186 \\
$\begin{array}{l}\text { DEGs between } \\
\text { ovary and testis: }\end{array}$ & 11,087 \\
Up-regulated & 6207 \\
genes in ovary & \\
Ovary-specific genes & 2997 \\
$\begin{array}{l}\text { Up-regulated } \\
\text { genes in testis }\end{array}$ & 4880 \\
Testis-specific genes & \\
Gonad up-regulated & 2853 \\
genes (G) & 3646 \\
$\begin{array}{l}\text { G-genes and DEGs } \\
\text { between ovary } \\
\text { and testis: }\end{array}$ \\
$\begin{array}{l}\text { Up-regulated } \\
\text { genes in ovary }\end{array}$ \\
$\begin{array}{l}\text { Ovary-specific genes } \\
\text { Up-regulated } \\
\text { genes in testis } \\
\text { Testis-specific genes }\end{array}$ \\
\hline
\end{tabular}

metabolic process', 'transmembrane transport' and 'DNA integration'. Complete results from the GO enrichment analyses are included as Additional file 1: Table S4. No remarkable differences between ovary and testis upregulated genes were detected when their GO term distributions were plotted (Fig. 1b).

\section{Candidate DEGs to be involved in sexual development}

We aimed to reveal genes involved in sex determination, sex differentiation and gonadal development pathways. To achieve this purpose, it is crucial to explore the DEGs between sexes. Thus, up-regulated expressed genes in ovaries and in testes were mined according to the transcriptome annotation and the published literature in search of putative sex-related genes. When different transcripts matched the same gene annotation their BLAST hits were manually cured, and then the fulllength transcript was chosen or, in the case that all of them were complete ORFs, the transcript with the highest expression was selected.

\section{Up-regulated genes in ovary}

The most expressed up-regulated genes in ovary libraries generally retrieved no annotations that allowed us to identify them. These top expressed genes mostly matched with genes tagged as 'gonad up-regulated' when they were compared with non-gonad tissues (Additional file 1: Table S2). The most highly expressed up-regulated genes that could be annotated were cytochrome c oxidase subunit 3 


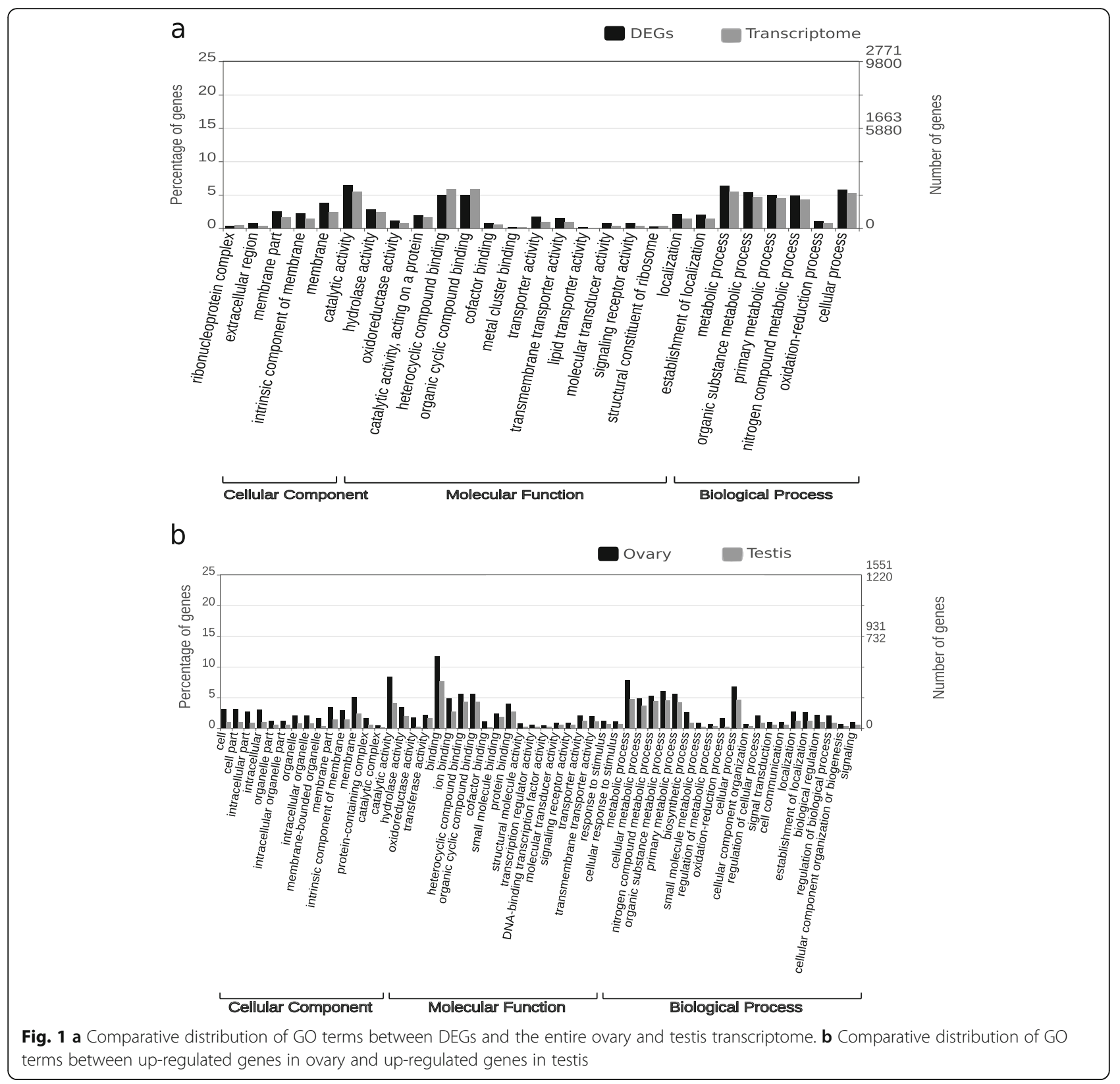

(Cox3), cellular retinoic acid-binding protein 2 (Crabp2), ferritin, death-associated inhibitor of apoptosis 1 (Diap1), ankyrin-like, annexin and NPC intracellular cholesterol transporter 2 homolog a (Npc2). However, our focus was to examine candidate genes to be involved in female sexual development within the 6207 up-regulated genes in ovary. A total of 15 sex-related DEGs were found to be up-regulated in ovary samples, being 10 out of them also gonad up-regulated genes and 3 considered ovary-specific genes (Table 4). Genes associated with vitellogenesis and ovary development were the DEGs that showed the higher expression levels: vitellogenin $(\mathrm{Vg})$, vitellogenin receptor
(VgR), cathepsin D, chorion peroxidase (Pxt) and profilin. Among up-regulated DEGs, they were also present prostaglandins metabolism-related genes, prostaglandin D synthase (Hpgds) and prostaglandin E synthase 2 (Pges2), along with farnesoic acid-O-methyl transferase (FAOMeT), heat shock cognate 70 (Hsc70), mothers against decapentaplegic 4 (Smad4), gonadotropin-releasing hormone receptor (Gnrhr), and progestin membrane receptor component 1 (Pgmrc1). Feminization-1b (Fem-1b), disrupted meiotic cDNA (Dmc1) and transcription factor Sox8 were detected as up-regulated genes in the ovary even though they were traditionally associated 
Table 4 Differentially expressed genes candidates to be involved in female sexual development

\begin{tabular}{|c|c|c|c|c|c|c|c|c|c|}
\hline Gene & Gene annotation & Sequence ID & $\begin{array}{l}\text { Length } \\
\text { (bp) }\end{array}$ & ORF & $\begin{array}{l}\text { Fold } \\
\text { change } \\
\text { (ovary/ } \\
\text { testis) }\end{array}$ & $\begin{array}{l}\text { FDR } \\
p \text {-value }\end{array}$ & $\begin{array}{l}\text { Mean TPM } \\
\text { ovaries }\end{array}$ & $\begin{array}{l}\text { Mean TPM } \\
\text { testes }\end{array}$ & $\begin{array}{l}\text { Gonad } \\
\text { up-regulated }\end{array}$ \\
\hline $\mathrm{Vg}$ & Vitellogenin & $\begin{array}{l}\text { TRINITY_DN69557_ } \\
\text { C0_g1_i2 }\end{array}$ & 7827 & complete & 8.53 & $9.16 \mathrm{E}-6$ & 635.87 & 106.46 & yes \\
\hline Vgr & Vitellogenin receptor & $\begin{array}{l}\text { TRINITY_DN75859_ } \\
\text { CO_g1_i3 }\end{array}$ & 5765 & complete & 61.24 & 0.00 & 754.94 & 16.39 & yes \\
\hline Hpgds & $\begin{array}{l}\text { Hematopoietic } \\
\text { prostaglandin } \\
\text { D synthase }\end{array}$ & $\begin{array}{l}\text { TRINITY_DN66544_ } \\
\text { c0_g1_i1 }\end{array}$ & 2050 & complete & 4.98 & $6.96 \mathrm{E}-3$ & 107.45 & 26.71 & yes \\
\hline $\begin{array}{l}\text { Cathepsin } \\
\text { D }\end{array}$ & Cathepsin D & $\begin{array}{l}\text { TRINITY_DN74459_ } \\
\text { C2_g2_i1 }\end{array}$ & 2138 & complete & 16.92 & $9.31 \mathrm{E}-8$ & 2637.5 & 224.02 & yes \\
\hline Pxt & Chorion peroxidase-like & $\begin{array}{l}\text { TRINITY_DN71711__ } \\
\text { CO_g1_i1 }\end{array}$ & 2419 & complete & 4872.33 & 0.00 & 2495.51 & 0.67 & yes \\
\hline Fem-1b & $\begin{array}{l}\text { Protein fem-1 } \\
\text { homolog B }\end{array}$ & $\begin{array}{l}\text { TRINITY_DN63971_- } \\
\text { C0_g1_i2 }\end{array}$ & 3646 & complete & 2.65 & $6.87 \mathrm{E}-3$ & 37.10 & 19.73 & no \\
\hline Profilin & Profilin & $\begin{array}{l}\text { TRINITY_DN61540_ } \\
\text { C0_g3_i2 }\end{array}$ & 904 & complete & 38.02 & 0.00 & 1768.14 & 68.09 & yes \\
\hline FAOMeT & $\begin{array}{l}\text { Farnesoic acid-O } \\
\text {-methyl transferase }\end{array}$ & $\begin{array}{l}\text { TRINITY_DN64401_ } \\
\text { c1_g5_i1 }\end{array}$ & 1726 & complete & 7.84 & $3.52 \mathrm{E}-6$ & 841.08 & 154.89 & yes \\
\hline $\mathrm{Hsc70}$ & $\begin{array}{l}\text { Heat shock } \\
\text { cognate } 70\end{array}$ & $\begin{array}{l}\text { TRINITY_DN71006_ } \\
\text { C1_g1_i1 }\end{array}$ & 2040 & 3' partial & 3.64 & $\begin{array}{l}4.79 \mathrm{E}- \\
03\end{array}$ & 674.77 & 259.44 & no \\
\hline Dmc1 & $\begin{array}{l}\text { Disrupted } \\
\text { meiotic CDNA }\end{array}$ & $\begin{array}{l}\text { TRINITY_DN62322_ } \\
\text { C4_g1_i1 }\end{array}$ & 1526 & complete & 5.30 & $9.59 \mathrm{E}-5$ & 222.61 & 60.22 & yes \\
\hline Sox8 & $\begin{array}{l}\text { Transcription } \\
\text { factor SOX-8 }\end{array}$ & $\begin{array}{l}\text { TRINITY_DN70088_ } \\
\text { C0_g1_i1 }\end{array}$ & 4022 & complete & 7.26 & 1.99E-3 & 3.57 & 0.58 & no \\
\hline Smad4 & $\begin{array}{l}\text { Mothers against } \\
\text { decapentaplegic } 4\end{array}$ & $\begin{array}{l}\text { TRINITY_DN62236_ } \\
\text { c4_g2_i4 }\end{array}$ & 3768 & complete & 24.67 & 0.00 & 97.11 & 4.91 & yes \\
\hline Gnrhr & $\begin{array}{l}\text { Gonadotropin-releasing } \\
\text { hormone receptor }\end{array}$ & $\begin{array}{l}\text { TRINITY_DN64884_ } \\
\text { C0_g1_i3 }\end{array}$ & 2199 & complete & 2493.02 & 0.00 & 62.82 & 0.03 & yes \\
\hline Pges2 & $\begin{array}{l}\text { Prostaglandin E } \\
\text { synthase } 2\end{array}$ & $\begin{array}{l}\text { TRINITY_DN55480_ } \\
\text { c0_g1_i1 }\end{array}$ & 1590 & complete & 4.00 & $2.74 \mathrm{E}-4$ & 51.2 & 18.82 & no \\
\hline Pgmrc1 & $\begin{array}{l}\text { Progestin membrane } \\
\text { receptor component } 1\end{array}$ & $\begin{array}{l}\text { TRINITY_DN74305_ } \\
\text { C2_g1_i3 }\end{array}$ & 1763 & complete & 3.17 & $9.65 \mathrm{E}-3$ & 17.48 & 7.48 & no \\
\hline
\end{tabular}

to male sexual development in previous studies (see Discussion).

\section{Up-regulated genes in testis}

Up-regulated genes in testis that showed the highest expression values also remained unannotated but they were identified as gonad up-regulated genes (Additional file 1: Table S3). The most expressed up-regulated annotated genes in testis were Kazal-like protease inhibitor MCPI, tenascin-X (TnxB), histone H1-delta (H1D), myosin light chain kinase (Mylk), histone H2A (H2A), RNA-directed RNA polymerase L and protein innexin-like. Regarding to DEGs associated with male sexual development, within the 4880 up-regulated genes in testis we identified 6 sexrelated genes, being 2 out of them gonad up-regulated genes and 5 considered as testis-specific genes (Table 5). Doublesex- and mab-3-related transcription factor 1 (Dmrt1) was the sex-related up-regulated gene with the highest expression. As Dmrt1, three transcription factors belonging to the SOX (Sry-related HMG box) family showed testis-specific expression, Sox5, Sox14 and Sox15. There were also up-regulated genes in testis that did not agree with the traditional literature about male sexual development, namely vitelline membrane outer layer protein 1 (Vmo1) and heat shock protein 90 (Hsp90) (see Discussion).

\section{Not differentially expressed genes}

Several genes that have been largely dealed as sex-related genes in crustaceans were investigated even though they were not DEGs in the present study (Table 6). No differential expression of these genes might respond to they are not involved in sexual development or because the differential expression took place in gonads before dissection. In detail, these genes comprised genes that were reported to act either triggering female or male determination or sex differentiation (e.g. sex-lethal, feminization-1a and -1c or forkhead box L2) or taking part in specific processes 
Table 5 Differentially expressed genes candidates to be involved in male sexual development

\begin{tabular}{|c|c|c|c|c|c|c|c|c|c|}
\hline Gene & Gene annotation & Sequence ID & $\begin{array}{l}\text { Length } \\
\text { (bp) }\end{array}$ & ORF & $\begin{array}{l}\text { Fold change } \\
\text { (ovary/testis) }\end{array}$ & $\begin{array}{l}\text { FDR } \\
p \text {-value }\end{array}$ & $\begin{array}{l}\text { Mean TPM } \\
\text { testes }\end{array}$ & $\begin{array}{l}\text { Mean TPM } \\
\text { ovaries }\end{array}$ & $\begin{array}{l}\text { Gonad } \\
\text { up-regulated }\end{array}$ \\
\hline$\overline{\text { Dmrt1 }}$ & $\begin{array}{l}\text { Doublesex- and } \\
\text { mab-3-related } \\
\text { transcription factor } 1\end{array}$ & $\begin{array}{l}\text { TRINITY_DN68477_ } \\
\text { c1_g1_i10 }\end{array}$ & 2920 & complete & -17.59 & 7.37E-9 & 19.54 & 0.82 & yes \\
\hline Vmo1 & $\begin{array}{l}\text { Vitelline membrane } \\
\text { outer layer protein } 1\end{array}$ & $\begin{array}{l}\text { TRINITY_DN62635_ } \\
\text { c0_g1_i2 }\end{array}$ & 1495 & complete & -9.18 & 4.01E-6 & 16.91 & 1.26 & yes \\
\hline Sox15 & $\begin{array}{l}\text { Putative transcription } \\
\text { factor SOX-15 }\end{array}$ & $\begin{array}{l}\text { TRINITY_DN73558_ } \\
\text { c1_g2_i1 }\end{array}$ & 1699 & $3^{\prime}$ partial & -11.60 & $1.90 \mathrm{E}-4$ & 5.37 & 0.38 & no \\
\hline Sox5 & $\begin{array}{l}\text { Transcription factor SOX- } \\
5\end{array}$ & $\begin{array}{l}\text { TRINITY_DN67052_ } \\
\text { C2_g1_i1 }\end{array}$ & 6054 & $5^{\prime}$ partial & -5.31 & 1.85E-4 & 5.13 & 0.69 & no \\
\hline Hsp90 & Heat shock protein 90 & $\begin{array}{l}\text { TRINITY_DN69393_- } \\
\text { CO_g1_i1 }\end{array}$ & 2573 & complete & -5.00 & $7.64 \mathrm{E}-3$ & 3.66 & 0.52 & no \\
\hline Sox14 & $\begin{array}{l}\text { Putative transcription } \\
\text { factor SOX-14 }\end{array}$ & $\begin{array}{l}\text { TRINITY_DN52668_ } \\
\text { CO_g1_i1 }\end{array}$ & 1704 & $5^{\prime}$ partial & -14.07 & $1.66 \mathrm{E}-3$ & 3.00 & 0.17 & no \\
\hline
\end{tabular}

later on ovary (e.g. estrogen-related receptor or follistatin) or testis (e.g. kinesin-like protein KIFC1) development and maturation. Due to the expression of some sexrelated genes was $\mathrm{TPM}<1$, they were not included in the final transcriptome. These genes with an extremely low expression were doublesex and mab-3-related transcription factor 11E (Dmrt11E), insulin-like androgenic factor (Iag) and Wnt4 transcription factor. Other interesting genes in reproduction with a documented preferential expression in non-gonad tissues were detected in our gonadal transcriptome, two members of the crustacean hyperglycemic hormone superfamily (Chh and Mih) and the ecdysone receptor $(\mathrm{EcR})$ gene.

Sequences of the sex-related genes listed in Table 4, Table 5 and Table 6 can be easily access in Additional file 3: File S1.

Finally, there were sex-related genes whose expression was not detected neither in the non-redundant transcriptome nor in the redundant one. This fact could be explained because the expression of these genes occurs in other tissues, or because they were expressed in gonads but not at the stage when animals were dissected or

Table 6 Inventory of sex-related genes not differentially expressed between sexes in this study

\begin{tabular}{|c|c|c|c|c|c|c|}
\hline Gene & Gene annotation & Sequence ID & Length (bp) & ORF & $\begin{array}{l}\text { FDR } \\
p \text {-value }\end{array}$ & $\begin{array}{l}\text { Gonad } \\
\text { up-regulated }\end{array}$ \\
\hline$\beta$-catenin & Beta-catenin & TRINITY_DN68450_c3_g1_i1 & 4487 & complete & 0.28 & no \\
\hline Err & Estrogen-related receptor & TRINITY_DN62849_c1_g1_i1 & 3564 & complete & 0.02 & no \\
\hline Fem-1a & Feminization factor 1a & TRINITY_DN72410_c0_g1_i3 & 2424 & complete & 0.27 & no \\
\hline Fem-1c & Feminization factor $1 \mathrm{c}$ & TRINITY_DN67155_c0_g1_i1 & 4405 & complete & 0.05 & no \\
\hline Foxl2 & Forkhead box L2 & TRINITY_DN67281_c5_g1_i1 & 3329 & complete & 0.95 & yes \\
\hline Fst & Follistatin & TRINITY_DN65522_c1_g2_i4 & 3175 & complete & 0.22 & no \\
\hline Kifc1 & Kinesin-like protein KIFC1 & TRINITY_DN70471_C2_g1_i10 & 3013 & complete & 0.25 & no \\
\hline Msl3 & Male-specific lethal 3 & TRINITY_DN62887_c0_g2_i3 & 3270 & complete & 0.20 & no \\
\hline Ptgr1 & Prostaglandin reductase 1 & TRINITY_DN59739_c0_g1_i3 & 1538 & complete & 0.99 & no \\
\hline$S x \mid$ & Sex-lethal & TRINITY_DN60874_c2_g1_i16 & 1340 & complete & 0.46 & no \\
\hline Tra-2 & Transformer 2 & TRINITY_DN66599_C7_g4_i2 & 1920 & 3' partial & 0.31 & no \\
\hline Vasa & Vasa & TRINITY_DN61866_c4_g1_i1 & 2619 & complete & 0.73 & yes \\
\hline Dmrt11E* & $\begin{array}{l}\text { Doublesex- and mab-3-related } \\
\text { transcription factor } 11 \mathrm{E}\end{array}$ & TRINITY_DN65796_c0_g1_i1 & 2931 & complete & & \\
\hline $\operatorname{lag}^{*}$ & Insulin-like androgenic gland factor & TRINITY_DN53120_C0_g1_i3 & 433 & internal & & \\
\hline Wnt4* & $\begin{array}{l}\text { Wingless-type MMTV integration } \\
\text { site family, member } 4\end{array}$ & TRINITY_DN24615_C0_g1_i1 & 425 & internal & & \\
\hline Chh & Crustacean hyperglycemic hormone & TRINITY_DN70124_C2_g1_i2 & 844 & complete & 0.93 & no \\
\hline Mih* & Molt inhibiting hormone & TRINITY_DN72393_c0_g2_i1 & 755 & complete & & \\
\hline $\mathrm{ECR}$ & Ecdysone receptor & TRINITY_DN75882_c1_g1_i6 & 5148 & complete & 0.96 & no \\
\hline
\end{tabular}


because they are not actually sex-regulators in $P$. serratus. Relevant non-expressed sex-related genes were doublesex (Dsx), fruitless (Fru), sex-determining region Y (Sry), transcription factors Sox9 and Sox10, cytochrome P450 aromatase, R-spondin-1 (Rspo1), steroidogenic factor 1 (Sf-1) and fibroblast growth factor 9 (Fgf9).

\section{Discussion}

Palaemon serratus is a relevant commercial species in some countries such as UK, Ireland, France, Spain and Portugal [21]. The lack of genomic information about $P$. serratus hinders the application of potential aquaculture techniques, especially those focused on reproductive traits related to sex dimorphism. Therefore, in the present work we attempted to unravel sex-related genes featured in sex determination, sex differentiation and/or gonadal development using a RNA-Seq approach. This is the first transcriptome analysis of the gonads of a Palaemon species and the first work that provides data about sex-related genes in P. serratus. Within Palaemonidae, sex-related genes have been only studied in two Macrobrachium species [8, 9, 22]. Here, a reference gonadal transcriptome was obtained using ovary and testis reads. Statistics indicated a high quality de novo assembly but only the $29.57 \%$ of the transcriptome could be annotated due to the scarcity of crustacean genomic sequences. Precisely, the most expressed up-regulated genes both in ovary and in testis were not annotated. As the non-annotated transcripts correspond to unknown novel transcripts or to unreviewed transcripts, these unannotated differentially expressed sequences deserve attention in future functional analyses about sex-related genes in this shrimp. Additionally, the complete transcriptome annotation is provided, largely increasing the sequence resources available for this species.

Sexual development includes several processes orchestrated by a variety of regulators. Overall, sex determination and sex differentiation are intricated processes not always clearly distinguishable because their signalling cascades can be integrated [11]. Sex determination mechanisms are widely divergent in animals, even between closely related species. This variability is due to the rapid evolution that sex-biased genes experience $[11,23]$ and is reflected to crustaceans, where is not uncommon for findings in sex-related genes to differ among species. This can be linked to there is no conserved sex determination pathway in decapods and it likely evolved independently several times, making difficult to trace master sex-regulators [24]. Back to P. serratus, heteromorphic sex chromosomes are absent [20] and none sex determination system has been documented. It was suggested that there is a sex chromosome dosage compensation mechanism involving Msl3 gene in the tissues of the palaemonid Macrobrachium nipponense [25] as in Drosophila. Unfortunately,
Msl3 was not a DEG between females and males in P. serratus, giving no hint to whether a heterogametic sex exists in this shrimp or not and what is it. Hence, we focused our efforts to study genes described as 'sex-related', mainly in crustaceans.

Orthologs of sex determination genes in the model arthropod Drosophila were found in our transcriptome database. Sxl and Tra-2 orthologs were detected without sex differential expression meanwhile Tra, Dsx and Fru were absent. In Drosophila sex is ruled by the genetic pathway Sxl-Tra/Tra-2-Dsx/Fru, being Sxl the master sex determinant gene $[12,26]$. It has been proposed that crustaceans may adopt the Drosophila sex determination pathway given the findings reported in some species as Penaeus monodon [27], Macrobrachium nipponense [28], Penaeus chinensis [29], Penaeus vannamei [30] and Eriocheir sinensis [31]. However, our data are in line with those that stand that these genes do not act in decapods as they do in insects (see review in [7]), as suggested for the lobster Sagmariasus verreauxi [32] or for the crab Scylla paramamosain [33].

In the nematode Caenorhabditis elegans, Fem-1 is a component of the sex determination signalling pathway that promotes the male phenotype [34, 35]. There are studies in decapods that pointed out the putative role of Fem- 1 genes in male sex determination $[18,36]$. Orthologs of the three members of the Fem-1 family were found in P. serratus but none of them was up-regulated in the testis. Fem-1a and Fem-1b were not DEGs between sexes whilst Fem-1b was found to be slightly up-regulated in the ovary. Particularly to Fem-1b, [37] detected a higher expression of this gene in the testes than in the ovaries of the prawn Macrobrachium nipponense, which is the opposite of what we found in P. serratus. Also in M. nipponense, [38] reported a ovary-specific Fem-1 gene that could be involved in sex determination or differentiation and in ovarian maturation in this species. Fem-1b ortho$\log$ was up-regulated in the ovary of P. serratus but it was not an ovary-specific gene given that it also exhibits a considerable expression in testis. We conclude that similarly to in Scylla paramamosain [17] and in Penaeus vannamei [39], our results seem to indicate that whether Fem-1 genes are involved in the sexual development in P. serratus has yet to be established given that they are expressed in both gonads.

The male-determining gene in most mammals is the $Y$ chromosome Sry gen $[40,41]$. SRY along with SF-1 induces testicular development through the activation of the transcription factor SOX9 [42]. SOX9 up-regulates via FGF9 the expression of the Dmrt1 gene, which is the major male sex differentiation gene, promoting testis development and maintenance [43]. Expression of Sry, Sf1, Sox9 and Fgf9 was not detected in the gonads of $P$. serratus. Some members of the Sox family were DEGs, 
Sox8 was up-regulated in ovaries and Sox5, Sox14 and Sox15 were specifically expressed in testes. The upregulation of Sox8 in females was unexpected as this gene has been related with testis development [12, 32]. Both Sox 5 and Sox 14 were previously identified as genes involved in male sex differentiation with expression in testis tissues [15, 44-46] but Sox15 has never been defined as a testis gene before. Nevertheless, the most relevant finding in $P$. serratus gonadal transcriptome is the testis-specific expression of the Dmrt1 gene.

In some vertebrate species Dmrt1 has been qualified as a sex-determining gene $[47,48]$. Moreover, Dmrt1 paralogs are the master sex determinant genes in medaka fish [49], frogs [50] and, recently in Sagmariasus verreauxi [11] as the first invertebrate species in which Dmrt1 determinates the sex. DMRTs are transcription factors characterized by the presence of a DM domain DNA binding motif. The relationship between DM domain genes and sex has been deeply investigated and as it is thought that their ancestral function was likely to determine gonadal sex and they subsequently expanded to control sexual dimorphism in other tissues [43]. Dmrt is the only gene family with a conserved function in sex determination across Animalia [11] and orthologs have been identified with a testis-restricted expression in the transcriptome of a few decapod species as the crabs Eriocheir sinensis [16] and Scylla paramamosain [17]. Keeping this in mind, the testis-specific Dmrt1 ortholog found in P. serratus should be considered the best candidate gene to be involved in the sex determination of this species. Future efforts should be directed to functionally characterize the Dmrt1 gene and to pursue upstream regulators and downstream targets. Another Dmrt gene was found in the transcriptome with an extremely low expression $(\mathrm{TPM}<1)$, the Dmrt11E gene that has been previously detected in some decapods. This gene exhibited a testis-biased expression in Macrobrachium rosenbergii [51] and an androgenic gland-biased expression in Sagmariasus verreauxi [32], and in both cases it was suggested that Dmrt11E is a male differentiation regulator via IAG. As the Dmrt11E expression in P. serratus gonads is very low, another tissue should be the primary site of expression instead of testis, likely the AG. Owing to its proved relationship with the IAG in other species, expression of Dmrt11E should be studied in different organs of $P$. serratus.

The IAG is the key regulator of male sex differentiation in the members of Malacostraca and its expression takes place exclusively in the androgenic gland (AG) of males. The Iag gene was characterized in several crustaceans, e.g. in the prawn Penaeus monodon [52], in the shrimps Penaeus vannamei [53], Macrobrachium lar, Palaemon paucides and P. pacificus [54], or in the spiny lobsters Sagmariasus verreauxi and Jasus edwardsii [32].
The expression level of the Iag gene in our gonadal transcriptome was very low $(\mathrm{TPM}=0.84)$, likely because in Palaemon species the AG is located along the sperm ducts and not in the testis [54], and they should not be dissected along with the testis. A better knowledge about Iag is crucial because its genetic manipulation-based biotechnology has the potential to dramatically transform the entire aquaculture industry [55]. Monosex culture has the potential to enhance the production because energy for reproduction is allocated to growing, so the individuals reach higher sizes [54]. As female shrimps grow larger and faster, all-female population cultures are preferred for $P$. serratus. It has been proved in different decapod species that AG removal feminizes males [13], but this surgical procedure frequently entails mortality, so get monosex cultures by genetic manipulation is highly attractive. All-male populations were achieved for Macrobrachium rosenbergii silencing Iag using RNA interference [14]. To obtain all-female populations in $P$. serratus we suggest exploring the manipulation of the Iag gene to induce female sex-reversal. We provide the first Iag sequence for $P$. serratus and, even though is a partial sequence, it has the potential to pave the way to further biotechnological approaches that enable the production of female monosex cultures. These aquaculture strategies may enhance $P$. serratus production and at the same time prevent the genetic deterioration of the wild stocks caused by overfishing.

Genes referred in literature as 'testis development' genes were also investigated. KIFC1 is a C-terminal kinesin motor protein that participates in acrosome biogenesis and nuclear reshaping during spermiogenesis in the palaemonids Macrobrachium nipponense [56] and Palaemon modestus [57] among other crustacean species. Kifc1 gene showed a high expression in the testis of $M$. nipponense and $P$. modestus but in both species this gene was also being expressed in other tissues, likely taking part in vesicle transportation processes [56], so is not strange that Kifc1 was not a DEG between ovary and testis in P. serratus. Temporal and spatial expression of Kifc1 during spermiogenesis in $P$. serratus could be address since its protein is vital in the formation of the acroframosome, an exclusive structure of caridean shrimp spermatids. Concerning to $\mathrm{DMC1}$, it plays a major role in meiotic recombination and has been associated to spermatogenesis in crustaceans [27]. Unlike in the crawfish Procambarus clarkii [18] and the crab Portunus trituberculatus [58], Dmc1 was not upregulated in the testis but in the ovary of Palaemon serratus. It is important to highlight that Dmc1 was a gonad up-regulated gene, most likely because it is expressed in meiotic germ cells [59], but its role in the spermatogenesis of $P$. serratus should not be directly attributed without further testing. Another gene related with germ cell development is vasa, an ATP-dependent RNA helicase. Since 
vasa plays a role in both oogenesis and spermatogenesis its expression was exclusively detected in the gonads of the shrimp Penaeus vannamei [60] or of the crab Scylla paramamosain [61]. In this sense it was not surprising that vasa was a gonad up-regulated gene respect to nongonad tissues but not a DEG between the ovary and the testis of $P$. serratus.

Regarding to female sex determination, Foxl2 gene encodes a conserved forkhead transcription factor preferentially expressed in the ovary of vertebrates, controlling the ovarian differentiation and maintenance by repression of testis-specific genes [62, 63]. If Dmrt1 is present, Foxl2 expression is repressed, but in the absence of Dmrt1, Foxl2 inhibits the male developmental pathway and promotes the female. The expression of Foxl2 showed a changing pattern among crustacean species, i.e. up-regulated in ovary [18], not DEG between sexes [31] or even up-regulated in testis [64]. Foxl2 was not a DEG between ovary and testis in $P$. serratus, which supports that the role of Foxl2 in sex determination in invertebrates remains unclear $[65,66]$. Dmrt1 also acts repressing the RSPO1-WNT4- $\beta$-catenin signalling pathway, another female sex determination cascade that promotes ovary development in vertebrates independently and complementary to the Foxl2-leading pathway [67-69]. Given that Rspo1 was not found in the transcriptome of $P$. serratus and Wnt4 and $\beta$-catenin were detected as not DEGs, the existence and function of this pathway is unknown in this shrimp, as it was already advanced for other decapods with orthologs found $[31,33]$. Thereby, vertebrate pathways leadered by Foxl2 and Rspo1 do not seem to determine female development in $P$. serratus in the light of our data. However, further experiments should confirm these lacks of function in sexual development.

Vitellogenesis, the production and accumulation of yolk, is crucial to oogenesis and ovarian maturation. In oviparous vertebrates vitellogenin synthesis is enhanced by $17 \beta$-estradiol E2, with the estrogen receptor (ER) and the HSP90 acting as mediators [70-73]. The elements of the E2-ER-HSP90 pathway were found in the transcriptome of decapod species [7, 64, 74] but only Hsp90 showed a higher expression in ovaries than in testes in the crab Scylla paramamosain [17]. An estrogen-related receptor gene (Err) was found in P. serratus without differential expression and Hsp90 was up-regulated in the testicular tissue, so our results agree that more studies are necessary to clarify if the E2-ER/ERR-HSP90 pathway exists in crustaceans and whether vitellogenesis it is regulated by estrogen-like hormones as it is in vertebrates. Another regulatory pathway that stimulates ovarian development and vitellogenesis in some decapods involves methyl farnesoate (MF), a crustacean juvenile hormone analogue [75, 76]. Farnesoic acid-O-methyl transferase (FAOMeT) encondes the enzyme that catalyzes formation of MF and it was up-regulated in the ovaries of $P$. serratus respect to testes and non-gonad tissues, indicating the putative role of this hormone in the ovarian maturation of the species. Vitellogenin $(\mathrm{Vg})$ and vitellogenin receptor (VgR), the main vitellogenesis genes, were up-regulated in the ovary of $P$. serratus as in multiple decapod species (e.g. [24] or [58]). The expression of $\mathrm{VgR}$ was higher than the expression of $\mathrm{Vg}$, likely because the hepatopancreas is considered the primary site of VG production instead of the ovary while the VGR allow VG uptake from the hemolymph by oocytes. Vitelline membrane outer layer protein 1-like gene (Vmo1) was strangely up-regulated in males, a finding also reported for the crab Eriocheir sinensis [31].

Other 'ovary development' genes were also explored in the gonadal transcriptome of $P$. serratus. Since prostaglandins (PGs) have been described as factors that promote ovary development in crustaceans [77], PG genes were studied in $P$. serratus. HPGDS and PGES2 showed an ovary-biased expression, so they might have an implication in female gonad development [78, 79]. Although PTGR1 is involved in the ovary development in the shrimp Penaeus monodon [80], it was not preferentially expressed in the ovaries of Palaemon serratus. Cathepsins have been also related with ovarian development in some crustaceans [22, 81, 82]. Cathepsin D is a needed protein for the formation of the yolk in vertebrates [83] and its gene was the only cathepsin gene up-regulated in the ovary of $P$. serratus. Other up-regulated genes in the ovary of $P$. serratus that are required for ovary maturation in other crustaceans were chorion peroxidase [31], profilin [84], Smad4 [85], Gnrhr [86] and Pgmrc1 [87]. Expression of Hsc70 was also up-regulated in the ovary of $P$. serratus, suggesting a putative role in reproductive events as in Macrobrachium rosengergii, where Hsc70 was enriched in the ovary [88]. Fst is known to be involved in folliculogenesis and ovary development in vertebrates [89], but it was not a DEG between the gonads of P. serratus, similarly to Eriocheir sinensis [31]. The expression of Fst should be examined throughout the stages of the ovarian development to evaluate whether it participates in it or not. Cytochrome P450 aromatase (Cyp19a) is also essential in the female gonadal development in vertebrates, converting androgens in estrogens. Several genes belonging to cytochrome P450 superfamily were detected in the transcriptome of $P$. serratus, but none of them was aromatase, an absence also found in the palaemonid Macrobrachium rosenbergii [90].

Lastly, two genes encoding two members of the $\mathrm{CHH}-$ superfamily were detected in the gonadal transcriptome with a very low and not differential expression between sexes: the crustacean hyperglycemic hormone (Chh) and the molt inhibiting hormone (Mih). $\mathrm{CHH}$ neuropeptides are multifunctional hormones with roles in reproduction, regulating AG proliferation or MF production among other 
activities (see review in [77]). The eyestalk is the preferential site of production of these neurohormones, but it was repeatedly demonstrated that these genes are also expressed in multiple tissues [91-93], including gonads in some species as in P. serratus. Likewise, as recent studies have demonstrated that ecdysteroids regulate vitellogenesis, ovarian maturation and spermatogenesis in decapods (see review in [78]), it is also interesting to highlight the expression of the ecdysone receptor (EcR) gene in both female and male $P$. serratus gonads.

\section{Conclusions}

This study encompasses the first large-scale RNA-Seq and comprehensive transcriptome analysis of Palaemon serratus gonads. More than 442 million of clean reads were obtained, 39,186 transcripts were assembled and annotated and 11, 087 out of them were found to be DEGs between ovary and testis. Sex-related genes were identified and their expression between sexes was studied. A wide inventory of sex-related genes is provided and thoroughly discussed in the framework of previous findings in other crustacean species. This is the first time that sex-related genes have been addressed in a Palaemon species, so this transcriptomic analysis will facilitate further experimental research that aimed to delve into the sex determination, sex differentiation and gonadal development mechanisms of $P$. serratus and close species. The candidate genes to be involved in sexual development might also shed light about the evolution of sex-regulators in crustaceans. Furthermore, we report some particularly interesting genes towards investigating future aquaculture applications for $P$. serratus.

\section{Methods}

Specimens of $P$. serratus used in this study were collected inshore from the Ártabro Gulf $\left(43^{\circ} 22^{\prime} 00^{\prime \prime} \mathrm{N}, 8^{\circ} 28^{\prime}\right.$ $\left.00^{\prime} \mathrm{W}\right)$ in the northwest of Spain using a fish trap. Animals were carried alive to the Aquarium Finisterrae dependencies (A Coruña, Spain) where they were kept at $18{ }^{\circ} \mathrm{C}$ in an aerated aquarium while they were sorted into sexes. According to [3], sex was determined by the presence (in males) or absence (in females) of the masculine appendix on the endopodite of the second pleopod. Shrimps (3-4.5 g body weight) were anesthetized on ice for $5 \mathrm{~min}$ prior to be sacrificed by dissection, and then gonads from three adult females and three adult males were quickly removed and directly immersed in liquid nitrogen. The development stage of the gonads was fully mature in all individuals. RNA isolation and library construction were carried out at AllGenetics \& Biology SL (A Coruña, Spain). Total RNA was extracted from the six samples by grinding them with a mortar and pestle under liquid nitrogen. The resulting powder was used for the extraction using NZYTech's Total RNA isolation kit (NZYTech). Pure RNA was eluted in a final volume of $30 \mu \mathrm{L}$ and then quantified and quality-checked in an Agilent 2100 Bioanalyzer (Agilent) using the Agilent RNA 6000 Kit (Agilent). Illumina's TruSeq Stranded mRNA Library Prep Kit (Illumina) was used to prepare six cDNA libraries following the manufacturer's instructions. Thus, one library per sample was prepared, i.e. three libraries from ovary tissues and three libraries from testis tissues were prepared, or in other words three biological replicates per sex. The fragment size distribution and concentration of the libraries were checked in the Agilent 2100 Bioanalyzer using the Agilent DNA1000 Kit (Agilent). Libraries were quantified using the Qubit dsDNA BR Assay Kit (ThermoFisher Scientific). All libraries were pooled in equimolar amounts, according to the quantification data. The pool was sequenced in two different lanes of a HiSeq 4000 PE100 platform (Illumina).

Raw reads quality control was performed using FastQC v0.11.5 [94]. Trimmomatic v0.35 [95] was used for raw reads trimming. Primer/adaptor sequences were removed and the first $15 \mathrm{bp}$ of the reads were cut. Trimmed reads shorter than $40 \mathrm{bp}$ were discarded. Both female and male gonads trimmed reads were assembled together to obtain a single transcriptome that included ovary and testis transcripts. Trinity software v2.4.0 [96] was used for de novo assembly of these high-quality short reads using default parameters settings $(\mathrm{Kmer}=25)$. Assembled transcriptome completeness was assessed with BUSCO v3.0.2 [97] using the Arthropoda database as reference. EvidentialGene tr2aacds pipeline [98] was used to reduce the transcriptome redundancy. Then BUSCO was run again to check the duplication level. Gene expression given as Transcript Per Million (TPM) was calculated by mapping back all ovary and testis trimmed reads together on the gonads assembled transcriptome (parameters: minimum allowed length fraction $=0.75$, similarity fraction $=0.95$ and $\max$ imum number of matching contigs $=4$ ) using the RNASeq tool of the CLC Genomics Workbench v11.0 (Qiagen). Only transcripts with a TPM $\geq 1$ were included in the definitive transcriptome. Ribosomal and mitochondrial contigs were identified by BLASTn [99] against the NCBI non-redundant (nr) database and they were also excluded from the final transcriptome. Functional annotation was carried out using the Trinotate v3.1.1 workflow (https://trinotate.github.io). In detail, sequence similarity of the assembled transcripts was evaluated using BLASTx [99] against the UniProtKB/Swiss-Prot database (E-value cutoff of 1e-5). TransDecoder v5.3.0 [100] was used to identify putative protein coding regions, including homology options as retention criteria for the candidates ORFs. Predicted ORFs were identified by BLASTp [99] queries against the UniProtKB/Swiss-Prot database (E-value cutoff of 1e-5). Protein functional domains were identified using HMMER3 [101] against the PFAM domain database. Signal peptide and transmembrane domains prediction 
was performed with SignalP v4.1 [102] and TMHMM v2.0 [103], respectively. WEGO [104] was used to plot the Gene Ontology (GO) functional classification and distribution of the annotated transcripts.

Trimmed reads of each gonad sample were mapped back separately on this reduced high-quality set of ovary and testis transcripts (parameters: minimum allowed length fraction $=0.75$, similarity fraction $=0.95$ and maximum number of matching contigs =4) using the RNA-Seq tool of the CLC Genomics Workbench v11.0 (Qiagen). Thus, expression of each transcript in each sample was calculated as Transcript Per Million (TPM). Subsequently, a DEA between ovary and testis samples was carried out in order to identify DEGs between ovaries and testes using the Differential Expression for RNA-Seq tool of the CLC Genomics Workbench v11.0 (Qiagen). GO enrichment analysis was conducted to reveal GO terms significantly enriched in DEGs using the CLC Genomics Workbench v11.0 (Qiagen). Transcriptomic SRA data (NCBI Sequence Read Archive) from other P. serratus tissues, larvae (SRR4341161-2) and muscle (SRR4341163-4), was used to identify differentially expressed genes (DEGs) between gonad tissues (ovary and testis) and non-gonad tissues (larvae and muscle). Firstly, SRA reads quality was checked with FastQC v0.11.5 [94] and Trimmomatic v0.35 [95] was used to trim the reads as follows: HEADCROP:15 TRAILING:25 MINLEN:40. SRA trimmed reads were mapped on the non-redundant and reduced gonads transcriptome to calculate the gene expression (TPM) of the assembled transcripts in the larvae and muscle samples. Pairwise differential expression analyses (DEAs) were performed between gonad and non-gonad samples (ovaries vs. larvae, ovaries vs muscle, testes vs larvae and testes vs muscle) using the CLC Genomics Workbench v11.0 (Qiagen). Up-regulated expressed genes in gonad tissues were tagged with a ' $G$ ' (gonad up-regulated) in the transcriptome annotation table.

\section{Supplementary information}

Supplementary information accompanies this paper at https://doi.org/10. 1186/s12864-019-6157-4.

Additional file 1: Table S1. Annotation table of the non-redundant $P$. serratus ovary and testis transcriptome. Table S2. Full list of up-regulated genes in ovary. Table S3. Full list of up-regulated genes in testis. Table S4. Results of $\mathrm{GO}$ enrichment analyses.

Additional file 2: Figure S1. Volcano plot of differentially expressed genes (DEGs) between ovary and testis samples. Not differentially expressed genes are shown with black dots meanwhile DEGs are depicted with red dots.

Additional file 3: File S1. Sequences of the discussed sex-related genes.

\section{Abbreviations}

AG: Androgenic gland; Bp: Base pair; Chh: Crustacean hyperglycemic hormone; Cox3: Cytochrome c oxidase subunit 3; Crabp2: Cellular retinoic acid-binding protein; Cyp19a: Cytochrome P450 aromatase; DEA: Differential expression analysis; DEG: Differentially expressed gene; Diap1: Death- associated inhibitor of apoptosis 1; Dmc1: Disrupted meiotic cDNA; Dmrt: Doublesex- and mab-3-related transcription factor; Dsx: Doublesex; E2: 17ß-estradiol E2; Ecr: Ecdysone receptor; Er: Estrogen receptor; Err: Estrogen-related receptor; FAOMeT: Farnesoic acid-O-methyl transferase; FDR: False discovery rate; Fem-1: Feminization-1; Fgf9: Fibroblast growth factor 9; Foxl2: Forkhead box L2; Fru: Fruitless; Gnrhr: Gonadotropin-releasing hormone receptor; GO: Gene ontology; H1D: Histone H1D; H2A: Histone H2A; Hpgds: Hematopoietic prostaglandin D synthase; Hsc70: Heat shock cognate 70; Hsp90: Heat shock protein 90; lag: Insulin-like androgenic factor; KIFC1: Kinesin-like protein KIFC1; MF: Methyl farnesoate; Mih: Molt inhibiting hormone; Msl3: Male-specific lethal 3; Mylk: Myosin light chain kinase; NCBI: National Center for Biotechnology Information; Npc2: NPC intracellular cholesterol transporter 2 homolog a; nr: NCBI non-redundant and nucleotide database; ORF: Open Reading Frame; PE: Paired-end; Pges2: Prostaglandin E synthase 2; Pgmrc1: Progestin membrane receptor component 1; Ptgr1: Prostaglandin reductase 1; Pxt: Chorion peroxidase; Rspo1: R-spondin1; Sf-1: Steroidogenic factor 1; Smad4: Mothers against decapentaplegic 4; Sox: Sry-related HMG box; SRA: Sequence Read Archive; Sry: Sex-determining region Y; Sxl: Sex-lethal; TnxB: Tenascin-X; TPM: Transcript Per Million;

Tra2: Transformer 2; Vg: Vitellogenin; VgR: Vitellogenin receptor;

Vmo1: Vitelline membrane outer layer protein 1; Wnt4: Wingless-type MMTV integration site family, member 4

\section{Acknowledgements}

We thank Dr. Ignacio Alborés for the dissection of the gonads, and the Aquarium Finisterrae of A Coruña for letting us use its dependencies. We also thank the anonymous reviewers for their improvements in the manuscript.

\section{Ethics and consent to participate}

Not applicable. No approval by an ethical committee was required to achieve the goals of the present study because experimental work was accomplished with an unregulated marine invertebrate.

\section{Authors' contributions}

AML conceived the study and designed the experiment. IGC, CM and AP carried out the bioinformatics analyses and interpreted the data. IGC wrote the manuscript and prepared the figures and tables. All authors reviewed drafts of the manuscript and approved its final version.

\section{Funding}

This work was funded by a CTM2014-53838-R grant from the Spanish Government (Ministerio de Economía y Competitividad) and by a ED431C 2018/S7 grant from Xunta de Galicia (Programa de Investigación Competitiva do Sistema Universitario Galego, Modalidade de grupos de referencia competitiva: Grupo de Investigación en Biología Evolutiva). I. GonzálezCastellano was supported by a FPU scholarship and a FPU mobility grant from Ministerio de Educación y Formación Profesional (Spain), FPU15/05265 and EST17/00257 respectively.

Availability of data and materials

The datasets generated and/or analyzed during the current study are available in the NCBI Sequence Read Archive (SRA) repository (accession numbers SRR8631955-SRR8631960) but restrictions apply to the availability of these data, and so they are not publicly available until article publication.

Consent for publication

Not applicable.

\section{Competing interests}

The authors declare that they have no competing interests.

\section{Author details}

'Universidade da Coruña, Departamento de Biología and Centro de Investigaciones Científicas Avanzadas (CICA), 15071 A Coruña, Spain. ${ }^{2}$ Università degli Studi di Trieste, Dipartimento di Scienze della Vita, 34127 Trieste, Italy. 
Received: 27 June 2019 Accepted: 9 October 2019

Published online: 22 October 2019

\section{References}

1. Udekem d'Acoz, C. d'. Inventaire et distribution des crustacés décapodes de l'Atlantique nord-orienal, de la Méditerranée et des eaux continentals adjacentes au nord de 25 N. Collection Patrimoines Naturels (Muséum National d'Histoire Naturelle (S.P.N.)). 1999;40.

2. Figueras AJ. Biología y pesca del camarón (Palaemon adpersus y Palaemon serratus) en la ría de Vigo. Facultad de Ciencias Biológicas. 1984.

3. González-Ortegón E, Cuesta JA. An illustrated key to species of Palaemon and Palaemonetes (Crustacea: Decapoda: Caridea) from European waters, including the alien species Palaemon macrodactylus. J Mar Biol Assoc UK. 2006;86:93-102.

4. Fahy E, Forrest N, O'Toole M, Mortimer R, Carroll J. Indicators of performance in the fishery for shrimp Palaemon serratus (Pennant) in Irish coastal waters. J Shellfish Res. 2006;25:1021-6.

5. Romana-Eguia MRR, Ikeda M, Kijima A. Marker-aided genetic stock management: prospects in Philippine aquatic biodiversity conservation and aquaculture. In Resource Enhancement and Sustainable Aquaculture Practices in Southeast Asia: Challenges in Responsible Production of Aquatic Species: Proceedings of the International Workshop on Resource Enhancement and Sustainable Aquaculture Practices in Southeast Asia 2014 (RESA) (pp. 213-222). Aquaculture Department, Southeast Asian Fisheries Development Center. 2015

6. Perina A, Marí-Mena N, Torrecilla T, González-Tizón AM, González-Castellano I, González-Ortegón E, et al. Assessment of genetic diversity and population structure of the common littoral shrimp Palaemon serratus (Pennant, 1777) by microsatellites: Towards a sustainable management. Aquatic Conserv: Mar Freshw Ecosyst. 2019:1-9.

7. Chandler JC, Aizen J, Fitzgibbon QP, Elizur A, Ventura T. Applying the power of transcriptomics: understanding male sexual development in decapod Crustacea. Integr Comp Biol. 2016:56:1144-56.

8. Jung $H$, Yoon BH, Kim WJ, Kim DW, Hurwood DA, Lyons RE, et al. Optimizing hybrid de novo transcriptome assembly and extending genomic resources for giant freshwater prawns (Macrobrachium rosenbergii): the identification of genes and markers associated with reproduction. Int J Mol Sci. 2016;17:690

9. Ma K, Qiu G, Feng J, Li J. Transcriptome analysis of the oriental river prawn, Macrobrachium nipponense using 454 pyrosequencing for discovery of genes and markers. PloS One. 2012;7:e39727.

10. Guo Q, Li S, Lv X, Xiang J, Sagi A, Manor R, et al. A putative insulin-like androgenic gland hormone receptor gene specifically expressed in male Chinese shrimp. Endocrinology. 2018;159:2173-85.

11. Chandler JC, Elizur A, Ventura T. The decapod researcher's guide to the galaxy of sex determination. Hydrobiologia. 2017:1-20.

12. Kopp A. Dmrt genes in the development and evolution of sexual dimorphism. Trends Genet. 2012;28:175-84.

13. Ventura T, Rosen $\mathrm{O}$, Sagi A. From the discovery of the crustacean androgenic gland to the insulin-like hormone in six decades. Gen Comp Endocrinol. 2011;173:381-8.

14. Ventura T, Manor R, Aflalo ED, Weil S, Rosen O, Sagi A. Timing sexual differentiation: full functional sex reversal achieved through silencing of a single insulin-like gene in the prawn. Macrobrachium rosenbergii. Biol Reprod. 2012;86.

15. Powell D, Knibb W, Remilton C, Elizur A. De-novo transcriptome analysis of the banana shrimp (Fenneropenaeus merguiensis) and identification of genes associated with reproduction and development. Mar Genomics. 2015;22:71-8.

16. Zhang EF, Qiu GF. A novel Dmrt gene is specifically expressed in the testis of Chinese mitten crab Eriocheir sinensis. Dev Genes Evol. 2010;220:151-9.

17. Gao J, Wang X, Zou Z, Jia X, Wang Y, Zhang Z. Transcriptome analysis of the differences in gene expression between testis and ovary in green mud crab (Scylla paramamosain). BMC Genomics. 2014:15:585.

18. Meng XL, Liu P, Jia FL, Li J, Gao BQ. De novo transcriptome analysis of Portunus trituberculatus ovary and testis by RNA-Seq: identification of genes involved in gonadal development. PLoS One. 2015;10:e0128659.

19. Perina A, González-Tizón AM, Meilán IF, Martínez-Lage A. De novo transcriptome assembly of shrimp Palaemon serratus. Genom Data. 2017;11:89-91.

20. Torrecilla Z, Martínez-Lage A, Perina A, González-Ortegón E, González-Tizón AM. Comparative cytogenetic analysis of marine Palaemon species reveals a
$\mathrm{X} 1 \mathrm{X} 1 \times 2 \times 2 / \mathrm{X} 1 \mathrm{X} 2 \mathrm{Y}$ sex chromosome system in Palaemon elegans. Front Zool. 2017;14:47.

21. Kelly E, Tully O, Lehane B, Breathnach S. The shrimp (Palaemon serratus P.) fishery: Analysis of the resource in 2003-2007. BIM Fisheries Resource Series. 2008;8.

22. Jin S, Fu H, Zhou Q, Sun S, Jiang S, Xiong Y, et al. Transcriptome analysis of androgenic gland for discovery of novel genes from the oriental river prawn, Macrobrachium nipponense, using Illumina Hiseq 2000. PloS One. 2013;8:e76840

23. Parsch J, Ellegren $\mathrm{H}$. The evolutionary causes and consequences of sexbiased gene expression. Nat Rev Genet. 2013;14:83.

24. Rotllant G, Nguyen TV, Sbragaglia V, Rahi L, Dudley KJ, Hurwood D, et al. Sex and tissue specific gene expression patterns identified following de novo transcriptomic analysis of the Norway lobster Nephrops norvegicus. BMC Genomics. 2017:18:622.

25. Zhang YP, Sun SM, Fu HT, Ge XP, Qiao H, Zhang WY, et al. Characterization of the male-specific lethal 3 gene in the oriental river prawn Macrobrachium nipponense. Genet Mol Res. 2015;14:3106-20.

26. Camara N, Whitworth C, Van Doren M. The creation of sexual dimorphism in the Drosophila soma. Curr Top Dev Biol. 2008;83:65-107.

27. Leelatanawit R, Klinbunga S, Aoki T, Hirono I, Valyasevi R, Menasveta P. Suppression subtractive hybridization (SSH) for isolation and characterization of genes related to testicular development in the giant tiger shrimp Penaeus monodon. BMB Rep. 2008;41:796-802.

28. Qiao H, Fu H, Jin S, Wu Y, Jiang S, Gong Y, et al. Constructing and random sequencing analysis of normalized cDNA library of testis tissue from oriental river prawn (Macrobrachium nipponense). Comp Biochem Physiol Part D Genomics Proteomics. 2012;7:268-76.

29. Li S, Li F, Wen R, Xiang J. Identification and characterization of the sexdeterminer transformer-2 homologue in Chinese shrimp Fenneropenaeus chinensis. Sex Dev. 2012;6:267-78.

30. López-Cuadros I, García-Gasca A, Gomez-Anduro G, Escobedo-Fregoso C, Llera-Herrera RA, Ibarra AM. Isolation of the sex-determining gene Sex-lethal (SXI) in Penaeus (Litopenaeus) vannamei (Boone, 1931) and characterization of its embryogenic, gametogenic, and tissue-specific expression. Gene. 2018:668:33-47.

31. Liu Y, Hui M, Cui Z, Luo D, Song C, Li Y, et al. Comparative transcriptome analysis reveals sex-biased gene expression in juvenile Chinese mitten crab Eriocheir sinensis. PLoS One. 2015;10:e0133068.

32. Chandler JC, Aizen J, Elizur A, Battaglene SC, Ventura T. Male sexual development and the androgenic gland: novel insights through the de novo assembled transcriptome of the eastern spiny lobster Sagmariasus verreauxi. Sex Dev. 2016;9:338-54.

33. Yang X, Ikhwanuddin M, Li X, Lin F, Wu Q, Zhang Y, et al. Comparative transcriptome analysis provides insights into differentially expressed genes and long non-coding RNAs between ovary and testis of the mud crab (Scylla paramamosain). Mar Biotechnol. 2018;20:20-34.

34. Doniach T, Hodgkin J. A sex-determining gene, fem-1, required for both male and hermaphrodite development in Caenorhabditis elegans. Dev Biol. 1984;106:223-35.

35. Gaudet J, VanderElst I, Spence AM. Post-transcriptional regulation of sex determination in Caenorhabditis elegans: widespread expression of the sexdetermining gene fem-1 in both sexes. Mol Biol Cell. 1996;7:1107-21.

36. Song C, Cui Z, Hui M, Liu Y, Li Y. Molecular characterization and expression profile of three Fem-1 genes in Eriocheir sinensis provide a new insight into crab sex-determining mechanism. Comp Biochem Physiol B Biochem Mol Biol. 2015;189:6-14.

37. Rahman NM, Fu H, Qiao H, Jin S, Bai H, Zhang W, et al. Molecular cloning and expression analysis of Fem $1 \mathrm{~b}$ from oriental river prawn Macrobrachium nipponense. Genet Mol Res. 2016;15.

38. Ma KY, Liu ZQ, Lin JY, Li JL, Qiu GF. Molecular characterization of a novel ovary-specific gene fem-1 homolog from the oriental river prawn Macrobrachium nipponense. Gene. 2016;575:244-52.

39. Galindo-Torres P, Ventura-López C, Llera-Herrera RA, Ibarra AM. A natural antisense transcript of the fem-1 gene was found expressed in female gonads during the characterization, expression profile, and cellular localization of the fem-1 gene in Pacific white shrimp Penaeus vannamei. Gene. 2019;706:19-31.

40. Sinclair AH, Berta P, Palmer MS, Hawkins JR, Griffiths BL, Smith MJ, et al. A gene from the human sex-determining region encodes a protein with homology to a conserved DNA-binding motif. Nature. 1990;346:240. 
41. Kashimada K, Koopman P. Sry: the master switch in mammalian sex determination. Development. 2010;137:3921-30.

42. Sekido R, Lovell-Badge R. Sex determination involves synergistic action of SRY and SF1 on a specific Sox9 enhancer. Nature. 2008;453:930.

43. Matson CK, Zarkower D. Sex and the singular DM domain: insights into sexual regulation, evolution and plasticity. Nat Rev Genet. 2012;13:163.

44. Denny P, Swift S, Connor F, Ashworth A. An SRY-related gene expressed during spermatogenesis in the mouse encodes a sequence-specific DNAbinding protein. EMBO J. 1992;11:3705-12

45. Qiao H, Xiong YW, Jiang SF, Fu HT, Sun SM, Jin SB, et al. Gene expression profile analysis of testis and ovary of oriental river prawn Macrobrachium nipponense, reveals candidate reproduction-related genes. Genet Mol Res. 2015;14:2041-54.

46. Ma KY, Li JL, Qiu GF. Identification of putative regulatory region of insulinlike androgenic gland hormone gene (IAG) in the prawn Macrobrachium nipponense and proteins that interact with IAG by using yeast two-hybrid system. Gen Comp Endocr. 2016;229:112-8.

47. Marchand O, Govoroun M, D'Cotta H, McMeel O, Lareyre JJ, Bernot A, et al. DMRT1 expression during gonadal differentiation and spermatogenesis in the rainbow trout Oncorhynchus mykiss. BBA Gene Struct Expr. 2000;1493:180-7.

48. Smith CA, Katz M, Sinclair AH. DMRT1 is upregulated in the gonads during female-to-male sex reversal in ZW chicken embryos. Biol Reprod. 2003;68:560-70.

49. Matsuda M, Nagahama Y, Shinomiya A, Sato T, Matsuda C, Kobayashi T, et al. DMY is a Y-specific DM-domain gene required for male development in the medaka fish. Nature. 2002;417:559.

50. Yoshimoto S, Okada E, Umemoto H, Tamura K, Uno Y, Nishida-Umehara C, et al. A W-linked DM-domain gene, DM-W, participates in primary ovary development in Xenopus laevis. Proc Natl Acad Sci USA. 2008;105:2469-74.

51. Yu YQ, Ma WM, Zeng QG, Qian YQ, Yang JS, Yang WJ. Molecular cloning and sexually dimorphic expression of two Dmrt genes in the giant freshwater prawn Macrobrachium rosenbergii. Agric Res. 2014;3:181-91.

52. Mareddy VR, Rosen O, Thaggard HB, Manor R, Kuballa AV, Aflalo ED, et al. Isolation and characterization of the complete cDNA sequence encoding a putative insulin-like peptide from the androgenic gland of Penaeus monodon. Aquaculture. 2011:318:364-70.

53. Vázquez-Islas G, Garza-Torres R, Guerrero-Tortolero DA, Campos-Ramos R. Histology of the androgenic gland and expression of the insulin-like androgenic gland hormone precursor gene in the genital organ of Pacific white shrimp Litopenaeus vannamei. J Crustac Biol. 2014;34:293-9.

54. Banzai K, Izumi S, Ohira T. Molecular cloning and expression analysis of cDNAs encoding an insulin-like androgenic gland factor from three palaemonid species, Macrobrachium lar, Palaemon paucidens and $P$. pacificus. JARQ-Jpn Agr Res Q. 2012;46:105-14.

55. Ventura T, Sagi A. The insulin-like androgenic gland hormone in crustaceans: From a single gene silencing to a wide array of sexual manipulation-based biotechnologies. Biotechnol Adv. 2012;30:1543-50.

56. Wang YT, Mao H, Hou CC, Sun X, Wang DH, Zhou H, et al. Characterization and expression pattern of KIFC1-like kinesin gene in the testis of the Macrobrachium nipponense with discussion of its relationship with structure lamellar complex (LCX) and acroframosome (AFS). Mol Biol Rep. 2012;39:7591-8.

57. Hou CC, Yang WX. Acroframosome-dependent KIFC1 facilitates acrosome formation during spermatogenesis in the caridean shrimp Exopalaemon modestus. PloS One. 2013:8:e76065.

58. Jiang H, Xing Z, Lu W, Qian Z, Yu H, Li J. Transcriptome analysis of red swamp crawfish Procambarus clarkii reveals genes involved in gonadal development. PloS One. 2014;9:e105122.

59. Okutsu T, Kang BJ, Miwa M, Yoshizaki G, Maeno Y, Wilder MN. Molecular cloning and characterization of Dmc1, a gene involved in gametogenesis, from the whiteleg shrimp Litopenaeus vannamei. Fisheries Sci. 2010;76:961-9.

60. Aflalo ED, Bakhrat A, Raviv S, Harari D, Sagi A, Abdu U. Characterization of a vasa-like gene from the pacific white shrimp Litopenaeus vannamei and its expression during oogenesis. Mol Reprod Dev. 2007;74:172-7.

61. Wang Y, Chen Y, Han K, Zou Z, Zhang Z. A vasa gene from green mud crab Scylla paramamosain and its expression during gonadal development and gametogenesis. Mol Biol Rep. 2012;39:4327-35.

62. Uhlenhaut NH, Jakob S, Anlag K, Eisenberger T, Sekido R, Kress J, et al. Somatic sex reprogramming of adult ovaries to testes by FOXL2 ablation. Cell. 2009;139:1130-42.

63. Georges A, Auguste A, Bessière L, Vanet A, Todeschini AL, Veitia RA. FOXL2: a central transcription factor of the ovary. J Mol Endrocrinol. 2014;52:R17-33.
64. Peng J, Wei P, Zhang B, Zhao Y, Zeng D, Chen X, et al. Gonada transcriptomic analysis and differentially expressed genes in the testis and ovary of the Pacific white shrimp (Litopenaeus vannamei). BMC Genomics. 2015:16:1006

65. Adell T, Müller WE. Isolation and characterization of five Fox (Forkhead) genes from the sponge Suberites domuncula. Gene. 2004;334:35-46.

66. Teaniniuraitemoana V, Huvet A, Levy P, Klopp C, Lhuillier E, GaertnerMazouni N, et al. Gonad transcriptome analysis of pearl oyster Pinctada margaritifera: identification of potential sex differentiation and sex determining genes. BMC Genomics. 2014;15:491.

67. Kocer A, Pinheiro I, Pannetier M, Renault L, Parma P, Radi O, et al. Rspondin1 and FOXL2 act into two distinct cellular types during goat ovarian differentiation. BMC Dev Biol. 2008:8:36.

68. Garcia-Ortiz JE, Pelosi E, Omari S, Nedorezov T, Piao Y, Karmazin J, et al. Foxl2 functions in sex determination and histogenesis throughout mouse ovary development. BMC Dev Biol. 2009;9:36.

69. Matson CK, Murphy MW, Sarver AL, Griswold MD, Bardwell VJ, Zarkower D. DMRT1 prevents female reprogramming in the postnatal mammalian testis. Nature. 2011;476:101.

70. Fliss $A E$, Benzeno S, Rao J, Caplan AJ. Control of estrogen receptor ligand binding by Hsp90. J Steroid Biochem Mol Biol. 2000;72:223-30.

71. Yano I, Hoshino R. Effects of $17 \beta$-estradiol on the vitellogenin synthesis and oocyte development in the ovary of kuruma prawn (Marsupenaeus japonicus). Comp Biochem Physiol A Mol Integr Physiol. 2006;144:18-23.

72. Wu LT, Chu KH. Characterization of heat shock protein 90 in the shrimp Metapenaeus ensis: evidence for its role in the regulation of vitellogenin synthesis. Mol Reprod Dev. 2008;75:952-9.

73. Coccia E, Lisa ED, Cristo CD, Cosmo AD, Paolucci M. Effects of estradiol and progesterone on the reproduction of the freshwater crayfish Cherax albidus. Biol Bull. 2010;218:36-47.

74. Yan $H$, Cui $X$, Shen $X$, Wang $L$, Jiang $L$, Liu $H$, et al. De novo transcriptome analysis and differentially expressed genes in the ovary and testis of the Japanese mantis shrimp Oratosquilla oratoria by RNA-Seq. Comp Biochem Physiol Part D Genomics Proteomics. 2018;26:69-78.

75. Nagaraju GPC. Is methyl farnesoate a crustacean hormone? Aquaculture. 2007;1:39-54.

76. Paran BC, Fierro IJ, Tsukimura B. Stimulation of ovarian growth by methyl farnesoate and eyestalk ablation in penaeoidean model shrimp, Sicyonia ingentis Burkenroad, 1938. Aquac Res. 2010;41:1887-97.

77. Nagaraju GPC. Reproductive regulators in decapod crustaceans: an overview. J Exp Biol. 2011;214:3-16.

78. Reddy PS, Reddy PR, Nagaraju GPC. The synthesis and effects of prostaglandins on the ovary of the crab Oziotelphusa senex senex. Gen Comparative Endocr. 2004;135:35-41.

79. Wimuttisuk W, Tobwor P, Deenarn P, Danwisetkanjana K, Pinkaew D, Kirtikara K, et al. Insights into the prostanoid pathway in the ovary development of the penaeid shrimp Penaeus monodon. PloS One. 2013;8:e76934

80. Prasertlux S, Sittikankaew K, Chumtong P, Khamnamtong B, Klinbunga S. Molecular characterization and expression of the Prostaglandin reductase 1 gene and protein during ovarian development of the giant tiger shrimp Penaeus monodon. Aquaculture. 2011;322:134-41.

81. Qiu GF, Yamano K, Unuma T. Cathepsin C transcripts are differentially expressed in the final stages of oocyte maturation in kuruma prawn Marsupenaeus japonicus. Comp Biochem Physiol B Biochem Mol Biol. 2005; 140:171-81.

82. Zhao W, Chen L, Zhang F, Wu P, Li E, Qin J. Molecular characterization of cathepsin L cDNA and its expression during oogenesis and embryogenesis in the oriental river prawn Macrobrachium nipponense (Palaemonidae). Genet Mol Res. 2013;12:5215-25.

83. Retzek H, Steyrer E, Sanders EJ, Nimpf J, Schneider WJ. Molecular cloning and functional characterization of chicken cathepsin D, a key enzyme for yolk formation. DNA Cell Biol. 1992;11:661-72.

84. Shui $Y, X u Z H$, Shen HS, Zhou X. Molecular cloning and expression analysis of profilin in red swamp crayfish Procambarus clarkii. J Chem Pharm Res. 2014;6:425-31.

85. Li Y, Fang $Y$, Liu Y, Yang X. MicroRNAs in ovarian function and disorders. J Ovarian Res. 2015;8:51

86. Ngernsoungnern A, Ngernsoungnern $P$, Kavanaugh $S$, Sower SA, Sobhon $P$, Sretarugsa $P$. The identification and distribution of gonadotropin-releasing hormone-like peptides in the central nervous system and ovary of the giant freshwater prawn Macrobrachium rosenbergii. Invert Neurosci. 2008;8:49-57. 
87. Preechaphol R, Klinbunga S, Yamano K, Menasveta P. Molecular cloning and expression of progestin membrane receptor component 1 (Pgmrc1) of the giant tiger shrimp Penaeus monodon. Gen Comp Endocr. 2010;168:440-9.

88. Liu J, Yang WJ, Zhu XJ, Karouna-Renier NK, Rao RK. Molecular cloning and expression of two HSP70 genes in the prawn Macrobrachium rosenbergii. Cell Stress Chap. 2004;9:313.

89. Knight $\mathrm{PG}$, Glister $\mathrm{C}$. Potential local regulatory functions of inhibins, activins and follistatin in the ovary. Reproduction. 2001;121:503-12.

90. Thongbuakaew T, Siangcham T, Suwansa-ard S, Elizur A, Cummins SF, Sobhon $\mathrm{P}$, et al. Steroids and genes related to steroid biosynthesis in the female giant freshwater prawn Macrobrachium rosenbergii. Steroids. 2016; 107:149-60.

91. Nguyen TV, Rotllant GE, Cummins SF, Elizur A, Ventura T. Insights Into Sexual Maturation and Reproduction in the Norway Lobster (Nephrops norvegicus) via in Silico Prediction and Characterization of Neuropeptides and G Protein-coupled Receptors. Front Endocrinol. 2018;9.

92. Shi L, Li B, Zhou TT, Wang W, Chan SF. Functional and evolutionary implications from the molecular characterization of five spermatophore $\mathrm{CHH} / \mathrm{MIH} / \mathrm{GIH}$ genes in the shrimp Fenneropenaeus merguiensis. PloS One. 2018:13:e0193375.

93. Ventura-López C, Gómez-Anduro G, Arcos FG, Llera-Herrera R, Racotta IS, Ibarra AM. A novel $\mathrm{CHH}$ gene from the Pacific white shrimp Litopenaeus vannamei was characterized and found highly expressed in gut and less in eyestalk and other extra-eyestalk tissues. Gene. 2016;582:148-60.

94. Andrews S. FastQC: A Quality Control Tool for High Throughput Sequence Data. Babraham Bioinformatics. 2010.

95. Bolger AM, Lohse M, Usadel B. Trimmomatic: a flexible trimmer for Illumina sequence data. Bioinformatics. 2014;btu170.

96. Grabherr MG, Haas BJ, Yassour M, Levin JZ, Thompson DA, Amit I, et al. Trinity: reconstructing a full-length transcriptome without a genome from RNA-Seq data. Nat Biotechnol. 2011;29:644.

97. Simão FA, Waterhouse RM, loannidis P, Kriventseva EV, Zdobnov EM BUSCO: Assessing genome assembly and annotation completeness with single-copy orthologs. Bioinformatics. 2015;31:3210-2.

98. Gilbert D. EvidentialGene: tr2aacds, mRNA transcript assembly software; 2013

99. Altschul SF, Gish W, Miller W, Myers EW, Lipman DJ. Basic local alignment search tool. J Mol Biol. 1990;215:403-10.

100. Haas B, Papanicolaou A. Transdecoder (Find Coding Regions within Transcripts); 2012.

101. Eddy SR. Accelerated profile HMM searches. PLOS Comput Biol. 2011;7: e1002195.

102. Petersen TN, Brunak S, Von Heijne G, Nielsen H. SignalP 4.0: discriminating signal peptides from transmembrane regions. Nat Methods. 2011:8:785-6.

103. Krogh A, Larsson B, von Heijne G, Sonnhammer EL. Predicting transmembrane protein topology with a hidden Markov model: application to complete genomes. J Mol Biol. 2011;305:567-80

104. Ye J, Zheng $H$, Zheng $H$, Zhang $Y$, Chen J, Zhang Z, et al. WEGO: A web tool for plotting GO annotations. Nucleic Acids Res. 2006;34:293-7.

\section{Publisher's Note}

Springer Nature remains neutral with regard to jurisdictional claims in published maps and institutional affiliations.

Ready to submit your research? Choose BMC and benefit from:

- fast, convenient online submission

- thorough peer review by experienced researchers in your field

- rapid publication on acceptance

- support for research data, including large and complex data types

- gold Open Access which fosters wider collaboration and increased citations

- maximum visibility for your research: over $100 \mathrm{M}$ website views per year

At BMC, research is always in progress.

Learn more biomedcentral.com/submissions 